\title{
CONNETTERE \\ un disegno per annodare e tessere
}

\author{
Gaetano Ginex \\ Daniele Colistra
}

I docenti di Disegno dell'area dello Stretto (Università di Messina e Università di Reggio Calabria) hanno scelto il termine connettere come denominatore comune per le ricerche sviluppate dagli studiosi che vedono nell'UID un luogo comune di crescita e confronto disciplinare. L'area dello Stretto è un luogo denso di significati, specchio tra miti e realtà; racchiude memorie immerse oltre i confini del tempo. Un mare stretto tra due terre, ricco di voci e di visioni, un periglioso confine emblema di quel viaggio che ognuno deve compiere per ritrovarsi, luogo di dialoghi e relazioni tra civiltà e culture in eterna ricerca del superamento di conflitti e divisioni.

L'identità dell'area dello Stretto di Messina si fonda da sempre su connessioni fisiche, visive, commerciali, culturali, religiose, linguistiche. II connettere allude anche alle relazioni che il disegno intrattiene con gli innumerevoli campi del sapere. Un disegno che oggi, come nel Rinascimento, costituisce espressione tangibile delle attività umane di ideazione e di invenzione.

Connettere sottintende una relazione stretta fra identità differenti e disposte allo scambio; è qualcosa di profondamente diverso da ibridare, mescolare. Nel connettere, ciascuna identità mantiene la propria peculiarità e le proprie caratteristiche, le mette in gioco, le offre agli altri. 
Connettere mette al centro i legami, la reciprocità, lo scambio e il confronto, la complementarietà, il valore delle differenze. Le Scuole di disegno degli Atenei di Messina e di Reggio Calabria rappresentano in modo paradigmatico la sinergia basata sulle differenze. L'esperienza del Corso di laurea in Ingegneria di Messina risale al 1929, anno in cui è stato attivato il biennio propedeutico presso dell'Istituto di Disegno della Facoltà di Scienze. A Reggio la Scuola è nata negli anni Sessanta presso l'Istituto Universitario di Architettura; in essa, il disegno ha sempre avuto un ruolo centrale per la didattica e le attività di ricerca. Connettere, quindi, allude alle multiformi relazioni che intercorrono fra gli innumerevoli campi del sapere. Un termine colmo di possibilità interpretative, che si pone come spunto per indagare ed esplorare, attraverso comuni riflessioni, impianti multidisciplinari. Il Disegno è il connettivo per la conoscenza e la relazione tra campi culturali legati alle parole e alle cose, nel tentativo di oltrepassare il semplice pensiero razionale. Questo volume declina il tema del connettere attraverso le strutture fondamentali del disegno, individuando quattro differenti focus di approfondimento e associando a ciascuno di essi un personaggio mitologico. Si vuol intessere così un intreccio di significati per definire una visione della ricerca che in modo trasversale tocchi i temi del disegno, del rilievo, della multimedialità e della comunicazione.

II richiamo al mito favorisce quel 'vedere' latino e greco, per ritrovare gli esempi invariabili di tutte le cose che furono o mai saranno. Un disegno che riannoda i miti e le leggende, da Crono che formò il porto di Messina, a Poseidone ed Eracle reggino, fino ai piloni tra Santa Trada e Punta Faro che vigilano sullo Stretto quasi a richiamare una connessione eterna tra le comuni origini. II Disegno traccia infinite storie che si dissimulano nelle parole, generano figure, hanno insondabili profondità semantiche. Da questo punto di vista, il connettere assume le sembianze di un filo che annoda e tesse relazioni fra nuovi e rinnovati saperi.

Il primo focus è associato a Prometeo, titano che rubò il fuoco agli dei per donarlo al genere umano. L'etimo del nome rivela la sua natura: Prometeo è "colui che riflette prima". Il focus ha per tema la Teoria e la tecnica, ulteriormente declinate in tre parole chiave: Scienze della Rappresentazione, Didattica, Integrazione di saperi. In questo focus sono messe in evidenza le connessioni che il disegno mantiene con i fondamenti disciplinari: gli statuti teorici, la storia della rappresentazione, la geometria descrittiva, la percezione, ma anche le estensioni e le ramificazioni verso altri campi, soprattutto quelli più innovativi, in cui è necessaria la definizione di un corpus di principi, norme e prassi operative indispensabili per la riconoscibilità all'interno della comunità scientifica. Il focus accoglie i contributi in cui è centrale il valore epistemologico, indipendentemente dallo specifico campo di applicazione: analisi grafica, tassonomia, comunicazione, new media, nuovi strumenti per la rappresentazione e per il rilievo, didattica del disegno.

Il secondo focus porta il nome di Meti, figlia di Oceano e Teti. II suo nome significa 'prudenza' e la sua principale caratteristica consiste nel fatto che può trasformare il proprio aspetto a suo piacimento. II focus è quindi associato alla Mutazione della forma; le parole chiave sono Configurazione, Ideazione, Trasformazione. In questo focus sono raccolti i contributi in cui il disegno gioca un ruolo chiave nella trasformazione della realtà: il progetto architettonico e urbano, la prototipazione, il web visual, la grafica, il restauro, la riqualificazione del patrimonio materiale, il disegno per l'industria e la manifattura.

Mnemosine, figlia di Urano e Gea (il cielo e la terra) e madre delle Muse, rappresenta la capacità di ricordare; essa diede il nome agli oggetti affinché i mortali possano intendersi. A essa, e alla Costruzione della memoria, è dedicato il terzo focus, le cui parole chiave sono Documentazione, Riproduzione, Virtualità. In questo senso, il connettere awviene attraverso la conservazione del passato e la sua declinazione in forme che lo possano rievocare, attualizzare e rendere intellegibile.

Abbiamo visto in Hermes, messaggero degli dei e padre dell'ermeneutica, la figura adatta a 
rappresentare il quarto e ultimo focus, dedicato al Racconto dei luoghi e delle cose, tramite le parole chiave Narrazione, Visualità, New Media. Secondo la retorica classica, la narrazione consiste nell'esposizione obiettiva di un avvenimento. Da questo punto di vista, una narrazione effettuata tramite il disegno ha il potere di connettere oggetti, avvenimenti e idee mediante forme differenti (fotografia, fumetto, graphic design, infografica...), facendo leva anche sulle potenzialità di divulgazione e integrazione sociale offerte dai nuovi strumenti per la narrazione multisensoriale.

Per citare questo capitolo: Ginex Gaetano, Colistra Daniele (2020). Connettere. Un disegno per annodare e tessere/Connecting. Drawing for weaving relationship. In Arena A., Arena M., Brandolino R.G., Colistra D., Ginex G., Mediati D., Nucifora S., Raffa P. (a cura di). Connettere. Un disegno per annodare e tessere. Atti del $42^{\circ}$ Convegno Internazionale dei Docenti delle Discipline della Rappresentazione/Connecting. Drawing for weaving relationships. Proceedings of the 42th International Conference of Representation Disciplines Teachers. Milano: FrancoAngeli, pp. 25-30. 


\title{
CONNECTING drawing for weaving relationships
}

\author{
Gaetano Ginex \\ Daniele Colistra
}

The teachers of the disciplines of Representation who work in the area of the Strait (University of Messina and University of Reggio Calabria) have chosen the term connecting as the common denominator for the research developed by scholars who see in the UID a common place of growth and discussion on the issues of representation. The area of the Strait of Messina is a place filled with meanings, a mirror between myths and reality, which contains immersed memories beyond the confines of time. A narrow sea between two lands, rich in voices and visions, a perilous border emblematic of the journey that each person must make to find themselves, an eternal place of dialogue and relationships between civilizations and cultures in the eternal search to overcome conflicts and divisions.

The identity of the Strait of Messina area has always been based on physical, visual, commercial, cultural, religious, linguistic connections. Connecting also alludes to the relationships that representation maintains with the innumerable fields of knowledge. Representation, today as in the Renaissance, constitutes a tangible expression of the human activities of ideation and invention.

Connecting implies a close relationship between different identities, willing to exchange; it is deeply different from hybridizing, mixing. By connecting, each identity maintains its own peculiarity and characteristics, putting them into play, offering them to others. 
Connecting focuses on bonds, reciprocity, exchange and comparison, complementarity, the value of differences. The Schools of representation of the Universities of Messina and Reggio Calabria paradigmatically represent the synergy based on differences.

The Engineering Degree Course in Messina dates back to 1929; in that year it was activated at the Drawing Institute of the Faculty of Science. The Reggio School was founded in the 1960s at the University Institute of Architecture; in it, representation has always played a central role for teaching and research activities.

Connecting therefore alludes to the multifarious relationships that exist between the innumerable branches of knowledge. A term full of interpretative possibilities, which is used as a starting point to investigate and explore, through common reflections and multidisciplinary systems.

Drawing is the connective for knowledge and the relationship between cultural fields regarding ideas, words and things, in an attempt to go beyond simple rational thinking. This book declines the theme of connecting through the fundamental structures of drawing, identifying four different focuses of deepening and associating each of them with a mythological character. The aim is to trace an interweaving of meanings to define a vision of research that touches transversally on the themes of drawing, surveying, multimediality and communication.

The reference to myth favors that Latin and Greek 'vision', indispensable for finding the invariable examples of all things that were or ever will be. Drawing that aspires to unite myths and legends, from Cronus who formed the sickle-shaped port of Messina, to Poseidon and Heracles Rheginus, to the pylons of Santa Trada and Punta Faro that watch over the Strait as if to recall an eternal connection between their common origins. From this point of view, connecting will take on the appearance of a thread that ties and weaves relationships between new and renewed knowledge.

The first focus is associated with Prometheus, a titan who stole fire from the gods to donate it to the mankind. The etymology of the name reveals its nature: Prometheus is "the one who first reflects". The focus is on Theory and technique, further declined in three keywords: Sciences of Representation, Didactics, Integration of knowledge. This focus highlights the connections that Representation maintains with disciplinary foundations: the theoretical statutes, the history of representation, descriptive geometry, perception, but also extensions and ramifications to other fields, especially the more innovative ones, in which it is necessary to define a system of principles, rules and operating practices essential for accreditation within the scientific community. The focus also includes contributions in which epistemological value is central, regardless of the specific field of application: graphic analysis, taxonomy, communication, new media, new tools for representation and for surveying, teaching.

The second focus is named after Metis, daughter of Oceanus and Thetys. Her name means "prudence", and her main characteristic is being able to her appearance at will. The focus is therefore associated with the Mutation of form; the keywords are Configuration, Design, Transformation. This focus collects contributions in which drawing plays a key role in transforming reality: architectural and urban design, prototyping, web visual, graphics, restoration, redevelopment of the material heritage, design for the industry and manufacturing.

Mnemosyne, daughter of Uranus and Gaea (sky and earth) and mother of the Muses, represents the ability to remember; according to the myth, she gave names to objects so that mortals can understand each other. The third focus is dedicated to her, and to the Construction of memory; the keywords are Documentation, Representation, Virtuality. In this topic, connecting is expressed through the conservation of the past and its visualization in forms that can evoke, update and make it intelligible. 
We have seen in Hermes, messenger of the gods and father of hermeneutics, the right figure to represent the fourth and final focus, dedicated to the Story of places and things, through the keywords Storytelling, Visuality, New Media. According to classical rhetoric, narration consists in the objective exposition of an event. From this point of view, a narration carried out through drawing has the power to connect objects, events and ideas through different forms (photography, comics, graphic design, infographics...), also leveraging on the potential for dissemination and social integration offered from new tools for multisensory storytelling. 